flexibility are the key to finding success and happiness while working in Japan.

\section{Stuart Fraser}

Laboratory of Molecular Mouse Genetics, Institute for Toxicology, Johannes GutenbergUniversity Mainz, Obere Zahlbacher Strasse 67, Mainz 55131, Germany

\section{Science, conservation and fox-hunting}

Sir - Much evidence on the issue of foxhunting with hounds is either speculative, being based on questionnaire surveys, or contradictory, particularly where funds are provided by special-interest groups. The recent study done at Bristol University (P. J. Baker, S. Harris \& C. J. Webbon, Nature 419, 34; 2002) is noteworthy for attempting an experimental approach.

Baker et al. found that the temporary cessation of fox-hunting in Britain during the foot-and-mouth disease outbreak of 2001 had no impact on fox population density, and concluded that a permanent ban on hunting is unlikely to result in a dramatic increase in fox numbers. However, motor vehicles are the greatest killer of foxes in Britain, accounting for some $25 \%$ of deaths. Hunting with hounds accounts for only $6.3 \%$ of the 400,000 foxes killed annually. More than five times as many are killed by shooting and snaring as by hunting with hounds in lowland hunting areas (L. Burns, V. Edwards, J. Marsh, L. Soulsby \& M. Winter. Report of the Committee of Inquiry into Hunting with Dogs in England and Wales, Stationery Office, London; 2000; see www.huntinginquiry.gov.uk). Fox-hunting is an ineffective method of population control .

Instead, these data suggest that foxhunting harvests a sustainable off-take, which might represent a traditional form of community-based conservation. Such projects improve local tolerance towards wildlife and maintain biodiversity without statutory regulation and recurrent public funding. The British government has supported many such projects in developing countries, and is committed to doing the same in Britain as a signatory to the Convention on Biological Diversity.

The defence of fox-hunting on conservation grounds relies on two main predictions in the event of a ban: first, that voluntary maintenance of biodiversityrich fox habitats such as woodlands and hedgerows by landowners involved in hunting would decline; second, that landowners' tolerance of foxes would decline, increasing their persecution by other potentially less humane methods and so reducing fox numbers. Landowners may have the potential to reduce fox densities by shooting and snaring (M. Heydon \& J. Reynolds, J. Zool. 251, $265 ; 2000)$, but using these results to predict changes after any ban remains problematic.

The best way to test these predictions would be to build on the opportunistic approach attempted by Baker et al. by imposing a temporary, medium-term ban in randomly chosen areas and conducting independently funded research into its effects on a range of factors. This adaptive management approach would satisfy Lord Burns's recent recommendation not to rush a decision on whether to ban hunting. Although this approach has its pitfalls, we believe that, with careful planning, it would provide a firmer scientific basis for legislation than existing evidence.

N. Leader-Williams, T. E. E. Oldfield, R. J. Smith \& M. J. Walpole Durrell Institute of Conservation and Ecology, University of Kent at Canterbury, Canterbury CT2 7NS, Kent, UK

\section{Culture gap: in biology, what works, continues}

Sir — Despite the arguments reported in your News Feature "Bridging the culture gap” (Nature 419, 244-245; 2002), biologists already have a simple unifying rule, without the help of physicists. It is 'what works, continues' - usually stated in terms of the survival and reproduction of the fittest.

In answer to a posed question: phosphate is used to activate and deactivate proteins, as are methyl and ethyl groups and various saccharides, for the same reason that I currently use green and orange highlighters. At some time in the past they were there and functioned, and were incorporated into the system. Applied maths has its place in biology, especially where simple rules apply, in detecting signal in noise and defining practical limits.

Mendel was the first and most influential in this regard. His work was so clever, or so arcane, that it took 35 years to work out what he had discovered, and another 50 years for molecular genetics to explain the mechanism that causes dominance. Typically, Mendel's laws underestimate reality. The effects of most alleles on most characters are quantitative, polygenic and multi-factorial, rather than qualitative - tall versus short.

Compare an organism to an automated factory. Physics can explain all of the functions from electrons in transistors to computers in robots to metal-forming stresses and welding, but it has trouble with company balance sheets and share prices.
In business, the overriding factor is market share; in biology, habitat occupation. Hugh Fletcher

School of Biology and Biochemistry, Queen's University of Belfast, 97 Lisburn Road, Belfast BT9 7BL, UK

\section{Culture gap: physics still seeks its unifying theory}

Sir - I was somewhat bemused when reading your News Feature (Nature 419, 244-246; 2002). The view that "biology today is where physics was at the beginning of the twentieth century" misses a critical difference between the two disciplines. Biology has a grand unifying theory: it was published in 1859 by Charles Darwin as On the Origin of Species by Means of Natural Selection. The same cannot be said of physics, which continues to search for its theory of everything.

\section{J. Hosken}

Zoology Museum, University of Zurich,

Winterthurerstr 190, 8057 Zurich, Switzerland

\section{Patents limit medical potential of sequencing}

Sir - In your interesting Nature Science Update1 "24-hour genome dawns", you report on the prospect of a personal sequence in minutes, for less than $\$ 1,000$. Patents will present at least two major problems to the timely adoption of these technologies ${ }^{2,3}$.

First, some US companies will not license 'their' genes for testing by others, so any diagnostic chip would have to skip the patented gene estate of Myriad Genetics and similar outfits. Second, for those willing to license their genes nonexclusively for inclusion in diagnostic gene chips and similar tools, the stacked royalties payable on all the patented genes will make the tests prohibitively expensive.

Technological advances will benefit patients only if owners of diagnostic gene patents permit the technologies to be used and are reasonable in their demands for royalties, such as by limiting their expectations to a small fraction, say $1-3 \%$, of the marginal cost allocable to their genes ${ }^{4}$.

\section{Jon F. Merz}

Center for Bioethics, University of Pennsylvania, 3401 Market Street, Suite 320, Philadelphia, Pennsylvania 19104-3308, USA

\footnotetext{
1. http://www.nature.com/nsu/020923/020923-2.html; 24 September 2002

2. Schissel, A., Merz, J. F. \& Cho, M. K. Nature 402, 118 (1999).

3. Merz, J. F., Kriss, A. G., Leonard, D. G. B. \& Cho, M. K. Nature 415, 577-579 (2002).

4. Merz, J. F. Clin. Chem. 45, 324-330 (1999).
} 